\title{
MODEL PENERIMAAN APLIKASI BRISPOT BRI UNIT DENGAN PENDEKATAN TECHNOLOGY ACCEPTANCE MODEL (TAM)
}

\author{
BRISPOT APPLICATION ACCEPTANCE MODEL WITH THE APPROACH \\ TECHNOLOGY ACCEPTANCE MODEL (TAM)
}

\author{
Marco Bona Tua*1, Hartoyo ${ }^{* *}$, Lilik Noor Yuliati***) \\ ${ }^{*}$ Bank BRI AIW Jakarta 2 \\ Jl. Otto Iskandardinata No. 72. Jakarta Timur 13330, Indonesia \\ ${ }^{* *}$ Sekolah Bisnis, IPB University \\ Jl. Padjajaran Bogor 16151, Indonesia \\ ${ }^{* * *}$ Departemen Ilmu Keluarga dan Konsumen, Fakultas Ekologi Manusia, IPB University \\ Jl. Lingkar Akademik, Kampus Darmaga IPB, Bogor 16680, Indonesia
}

\begin{abstract}
BRISPOT is BRI's innovative step in Financial Technology (Fintech) services to accelerate the micro credit process, be more efficient, paperless and digital-based. This study analyzes the acceptance of the use of the BRISPOT application in BRI Kanca Karawang. One of the models used in analyzing technology acceptance is the Technology Acceptance Model (TAM). This research was conducted from December 2019 to February 2020. The population in this study amounted to 124 respondents with the criteria for respondents in this study were marketers who had used BRISPOT. Methods and data analysis using PLSSEM. The results showed that perceived resources and self efficacy had a significant effect on perceived ease of use, perceived ease of use had a significant effect on perceived usefulness, perceived usefulness had a significant effect on attitude toward using, and attitude toward using had a significant effect on actual use of BRISPOT. The managerial implication in this research is that management can improve the upload feature of business photos and debtors' collateral and add the BRISPOT employee care feature to the application so that respondents can immediately ask questions and get solutions to problems with features that are experiencing interference.
\end{abstract}

Keywords: BRISPOT, IPMA, PLS, TAM, sales marketing

\begin{abstract}
Abstrak: BRISPOT merupakan langkah inovatif BRI dalam layanan Financial Technology (Fintech) untuk mempercepat proses kredit mikro, lebih efisien, tanpa kertas dan berbasis digital. Penelitian ini menganalisis penerimaan penggunaan aplikasi BRISPOT di BRI unit supervisi kanca Karawang. Salah satu model yang digunakan dalam menganalisis penerimaan teknologi yaitu dengan menggunakan Technology Acceptance Model (TAM). Penelitian ini dilaksanakan dari bulan Desember 2019 sampai dengan Februari 2020. Populasi dalam penelitian ini berjumlah 124 responden dengan kriteria responden dalam penelitian ini adalah tenaga pemasar yang pernah menggunakan BRISPOT. Metode dan analisis data menggunakan PLS-SEM. Hasil penelitian menunjukkan perceived resources dan self efficacy signifikan terhadap perceived ease of use, perceived ease of use berpengaruh signifikan terhadap perceived usefulness, perceived usefulness berpengaruh signifikan terhadap attitude toward using, dan attitude toward using berpengaruh signifikan terhadap actual use BRISPOT. Implikasi manajerial dalam penelitian ini yaitu manajemen dapat memperbaiki fitur unggah foto usaha dan agunan debitur dan menambahkan fitur BRISPOT employee care pada aplikasi sehingga responden bisa langsung bertanya dan mendapatkan solusi atas permasalahan terhadap fitur yang mengalami gangguan.
\end{abstract}

Kata kunci: BRISPOT, IPMA, PLS, TAM, tenaga pemasar

\footnotetext{
${ }^{1}$ Corresponding author:

Email: mbonatua@gmail.com
} 


\section{PENDAHULUAN}

Perkembangan teknologi di industri perbankan menjadi tantangan baru di era digitalisasi saat ini. Transaksi di perbankan yang semula dari sistem konvensional perlahan beralih menjadi transaksi digital (Acturan, 2012). Hal tersebut mendorong inovasi dibidang jasa keuangan turut dipengaruhi oleh perkembangan teknologi. Salah satu bentuk inovasi jasa keuangan adalah melalui Financial Technology (FinTech). (Chrismantianto, 2017). Memasuki era digitalisasi perbankan, Bank BRI melakukan inovasi proses kredit mikro dari proses input manual menjadi full digital melalui BRISPOT.

BRISPOT menggunakan sistem berbasis Android dan koneksi melalui internet, sehingga memungkinkan putusan pinjaman untuk dilakukan di tempat. Dengan implementasi sistem BRISPOT tersebut, waktu untuk proses prakarsa pinjaman turun dari 3 (tiga) hari untuk pinjaman baru menjadi 2 (dua) hari, sedangkan untuk nasabah eksisting, pinjaman baru bisa diputus dihari yang sama. Total Penyaluran kredit mikro dengan menggunakan BRISPOT untuk kantor wilayah BRI Jakarta 2 seperti yang terlihat pada Gambar 1 .

BRISPOT sebagai salah satu aplikasi layanan pinjaman mikro yang telah dilakukan pengembangan sejak tahun 2017 mendorong permintaan kredit yang tinggi namun implementasi di lapangan oleh tenaga pemasar mikro (Mantri) di beberapa Kantor Cabang Jakarta 2 masih belum bisa mencapai target kerja yang telah ditetapkan. Dari 13 Kantor cabang yang menyalurkan kredit mikro ada sebanyak 6 Kantor Cabang yang realisasi posisi Desember 2018 belum mencapai target, keenam Kantor Cabang tersebut adalah Karawang, Depok, Cikampek, Radio Dalam, Pasar Minggu dan Cinere. Seharusnya dengan sistem baru menggunakan BRISPOT produktifitas Mantri dapat meningkat $30-40 \%$ per bulan per mantri namun keberhasilan dalam suatu sistem bergantung pada bagaimana proses menjalankan sistem tersebut, kemudahan penggunaan bagi pemakai, dan kemampuan pemakai sistem. Maka dari itu, penelitian ini menganalisis penerimaan penggunaan aplikasi BRISPOT bagi tenaga pemasar di BRI unit menggunakan Technology Acceptance Model (TAM).

Penerapan transformasi digital dan perancangan ulang business process pada perbankan tidaklah mudah untuk dilakukan sebab faktor sumber daya manusia sangat penting untuk diperhatikan dalam penerapan sistem baru (Rachbini et al. 2019) karena tingkat kesiapan pemakai untuk menerima sistem baru mempunyai pengaruh besar dalam menentukan sukses tidaknya penerapan sistem tersebut (Kustono, 2000). Salah satu model yang digunakan dalam menganalisis penerimaan teknologi yaitu dengan menggunakan model Technology Acceptance Model (TAM) (Rahardi, 2015). Penggunaan TAM selain dapat menjelaskan suatu sistem dapat diterima atau ditolak, metode ini juga memberikan masukan untuk memperbaiki suatu sistem teknologi agar lebih bisa diterima oleh penggunanya (Davis et al. 1989).

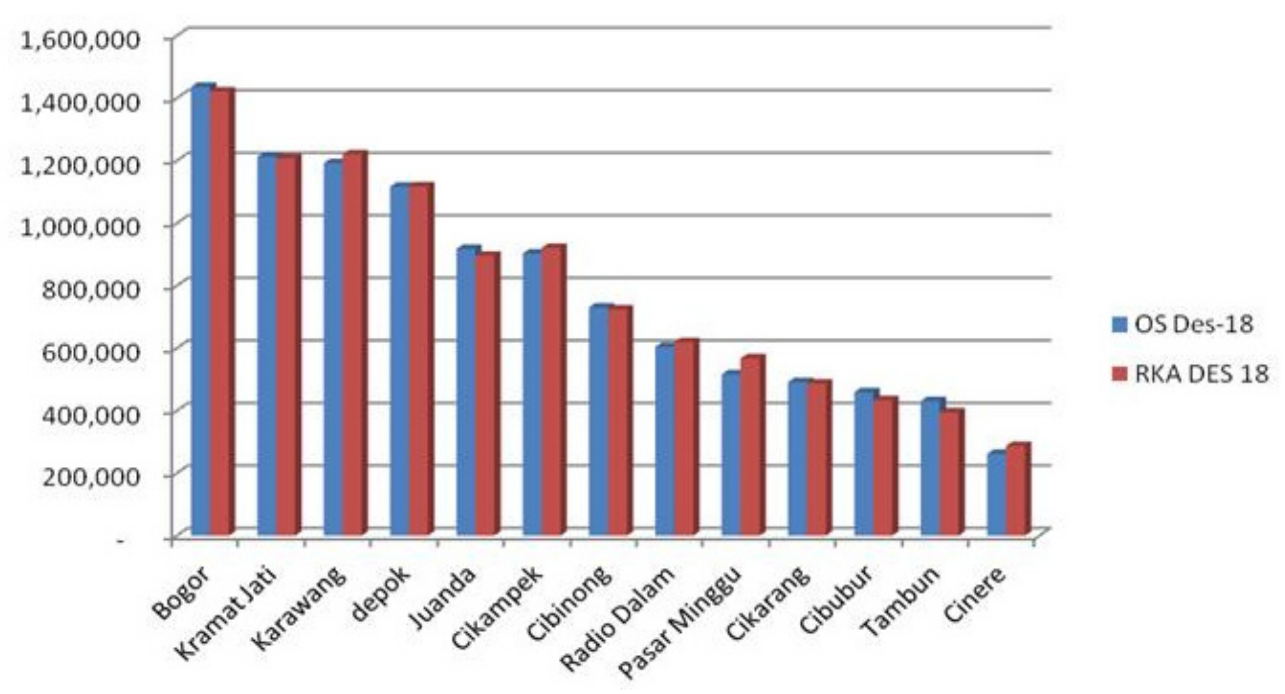

Gambar 1. Pencapaian kredit mikro kantor cabang BRI wilayah Jakarta 2 posisi 31 Desember 2018 
Menurut Davis (1989) dua keyakinan individu yang paling penting tentang penggunaan teknologi informasi adalah Perceived usefulness dan Perceived Ease of Use Persepsi kegunaan (PU) adalah seberapa banyak individu yang percaya bahwa menggunakan alat tertentu akan meningkatkan kemampuannya dalam menyelesaikan pekerjaan (Liu dan Li, 2009). Kegunaan yang dirasakan adalah penentu utama yang secara tegas memengaruhi keyakinan dan harapan pengguna untuk memanfaatkan inovasi. Menurut Venkatesh et al. (2012) Persepsi kemudahan penggunaan merupakan seberapa banyak pengguna menggunakan alat tertentu, dan bebas dari usaha.

Riquelme dan Rios (2010) menegaskan bahwa manfaat yang dirasakan memainkan peran penting dalam menentukan adopsi dan penggunaan layanan perbankan. Penelitian Simanjuntak (2019) tentang Analisis Kesiapan Teknologi terhadap Penerimaan Teknologi untuk mengevaluasi BNI Fleksi eForm. Berdasarkan hasil Analisis Technology Acceptance Model (TAM) Analisis dan Organizational Innovation Readiness (OITIRS), terdapat kesenjangan besar antara harapan pelanggan (atribut penting) dalam mengajukan kredit dibandingkan kesiapan teknologi melalui BNI Fleksi eForm. Model tingkat Kesiapan Teknologi BNI Fleksi eForm yang telah dianalisis adalah "Tidak Siap". Penelitian lain digital banking pada Bank BRI yang dilakukan Indraswari (2019) menjelaskan bahwa faktor perceived usefulness dan perceived ease of use pada analisis penerimaan teknologi terhadap pengguna BRI Mobile juga menunjukkan pengaruh positif terhadap behaviour intention.

Berdasarkan penelitian yang dilakukan oleh Ronald dan Amelia (2017) menjelaskan bahwa faktor-faktor yang berpengaruh positif terhadap minat menggunakan digital banking adalah perceived ease of use, perceived usefulness, perceived credibility, compatibility, personal innovativeness, and social influence. Pada penelitian ini variabel TAM berfokus pada pengaruh perceived ease of use, perceiveduselfulness, attitude toward using terhadap actual use BRISPOT. Selain variabel utama pada TAM, penelitian ini menambahkan variabel eksternal yaitu perceived resources, self efficacy dan social influence (internalization, identification, compliance) terhadap actual use BRISPOT. Penelitian dilakukan untuk : 1) menganalisis pengaruh perceived resources dan selfefficacy terhadap perceived ease of use BRISPOT, 2) menganalisis pengaruh social influence (internalizatio n,identification, compliance), perceived ease of use dan perceived usefulness terhadap attitude toward using BRISPOT, 3) menganalisis pengaruh perceived ease of use dan self efficacy terhadap perceived usefulness BRISPOT, 4) menganalisis pengaruh attitude toward using terhadap actual use BRISPOT dan 5) merumuskan implikasi manajerial yang dapat diterapkan bagi BRI Kanca Karawang dalam mengembangkan BRISPOT bagi keberlangsungan bisnis di unit kerja.

\section{METODE PENELITIAN}

Penelitian ini dilakukan di BRI kantor cabang Karawang yang memiliki 31 (tiga puluh satu) BRI unit dan semua BRI unit kantor cabang Karawang dijadikan tempat lokasi penelitian. Pengambilan data dilakukan selama tiga bulan mulai dari Desember 2019 s/d Februari 2020. Populasi pada penelitian ini berjumlah 124 tenaga pemasar dengan kriteria responden pada penelitian ini adalah tenaga pemasar (Mantri) yang sudah menggunakan aplikasi BRISPOT. Penelitian ini menggunakan data primer yang diperoleh secara langsung kepada tenaga pemasar melalui penyebaran kuesioner kepada 124 tenaga pemasar BRI Unit di Kanca Karawang.

Teknik pengumpulan data primer melalui Self administered questionnaire melalui google form (Rahadi, 2015). Teknik pengambilan responden menggunakan metode sensus. Metode dan analisis data menggunakan PLS-SEM. Berikut kerangkan pemikiran pada penelitian ini yang dapat dilihat pada Gambar 2.

TAM berfokus pada perceived ease of use, perceived uselfulness, attitude toward using, intenttion to use dan actual use (Wibowo et al. 2018) Pada penelitian ini peneliti tidak memasukan variabel intention to use, hal ini dikarenakan BRISPOT merupakan alat yang wajib digunakan oleh responden untuk memprakarsai kredit debitur. Selain menggunakan variabel-variabel TAM, Peneliti juga memasukan variabel eksogen kedalam penelitian yaitu perceived resources, self efficacy dan social influence (internalization, identification dan compliance) dalam menjelaskan proses penerimaan aplikasi BRISPOT.

Hipotesis dari penelitian ini berupa analisis pengaruh antar variabel terhadap penerimaan pengguna aplikasi BRISPOT berdasarkan pendekatan TAM. Hipotesis khusus pada penelitian ini adalah sebagai berikut: 
H1 : Perceived Resources berpengaruh positif terhadap Perceived Ease of Use BRISPOT

$\mathrm{H} 2$ : Self-efficacy berpengaruh positif terhadap Perceived Ease of Use BRISPOT

H3 : Self-Efficacy berpengaruh positif terhadap Usefulness BRISPOT

$\mathrm{H} 4$ : Internalization berpengaruh positif terhadap Attitude Toward Using BRSIPOT

H5 : Identification berpengaruh positif terhadap Attitude Toward Using BRSIPOT

H6 : Compliance berpengaruh negative terhadap Attitude Toward Using BRSIPOT

H7 : Perceived Ease of Use berpengaruh positif terhadap Perceived Usefulness BRISPOT

H8 : Perceived Ease of Use berpengaruh positif terhadap attitude toward usingBRISPOT

H9 : Perceived Usefulness berpengaruh positif terhadap attitude toward sing BRISPOT

H10 : Attitude Toward Using berpengaruh positif terhadap Actual Use BRISPOT

\section{HASIL}

\section{Karakteristik Responden}

Karakteristik responden meliputi jenis kelamin, usia, jenjang pendidikan, masa kerja, dan pengalaman menggunakan BRISPOT. Hasil penyebaran kuisoner menghasilkan 124 kuisoner yang memenuhi kelengkapan untuk diolah. tiga dari empat responden penelitian ini berjenis kelamin laki-laki dan $85 \%$ dari total seluruh responden berada pada rentang usia 26 tahun sampai dengan 35 tahun. Jenjang pendidikan responden pada penelitian ini mayoritas (85\%) adalah lulusan Sarjana (S1). Masa kerja Responden sudah bekerja di BRI dalam rentang kurun waktu 6 s.d 10 tahun Proporsi terbesar (40\%) responden sudah menggunakan BRISPOT selama 13 s.d 24 bulan.

\section{Deskripsi Indikator Variabel}

\section{Perceived Ease of Use}

Berdasarkan Tabel 1 lebih dari 90 persen responden mempersepsikan BRISPOT mudah digunakan, hanya kurang dari 2 persen responden yang menyatakan bahwa BRISPOT tidak mudah digunakan. Responden yang mempersepsikan BRISPOT tidak mudah digunakan adalah 2 dari 3 responden berjenis kelamin perempuan dengan masa kerja kurang dari 10 tahun dan sudah menggunakan BRISPOT selama satu tahun.

\section{Perceived Usefulness}

Berdasarkan hasil perhitungan dari top two boxes diketahui bahwa hampir seluruh responden menyatakan BRISPOT bermanfaat dalam pekerjaan Hanya kurang dari 2 persen responden yang menyatakan bahwa BRISPOT tidak bermanfaat dalam pekerjaan (Tabel 2). Responden yang mempersepsikan BRISPOT tidak bermanfaat adalah responden laki-laki dengan usia diatas 30 tahun yang memilik masa kerja di BRI lebih dari 10 tahun dan sudah menggunakan BRISPOT lebih dari 3 tahun.

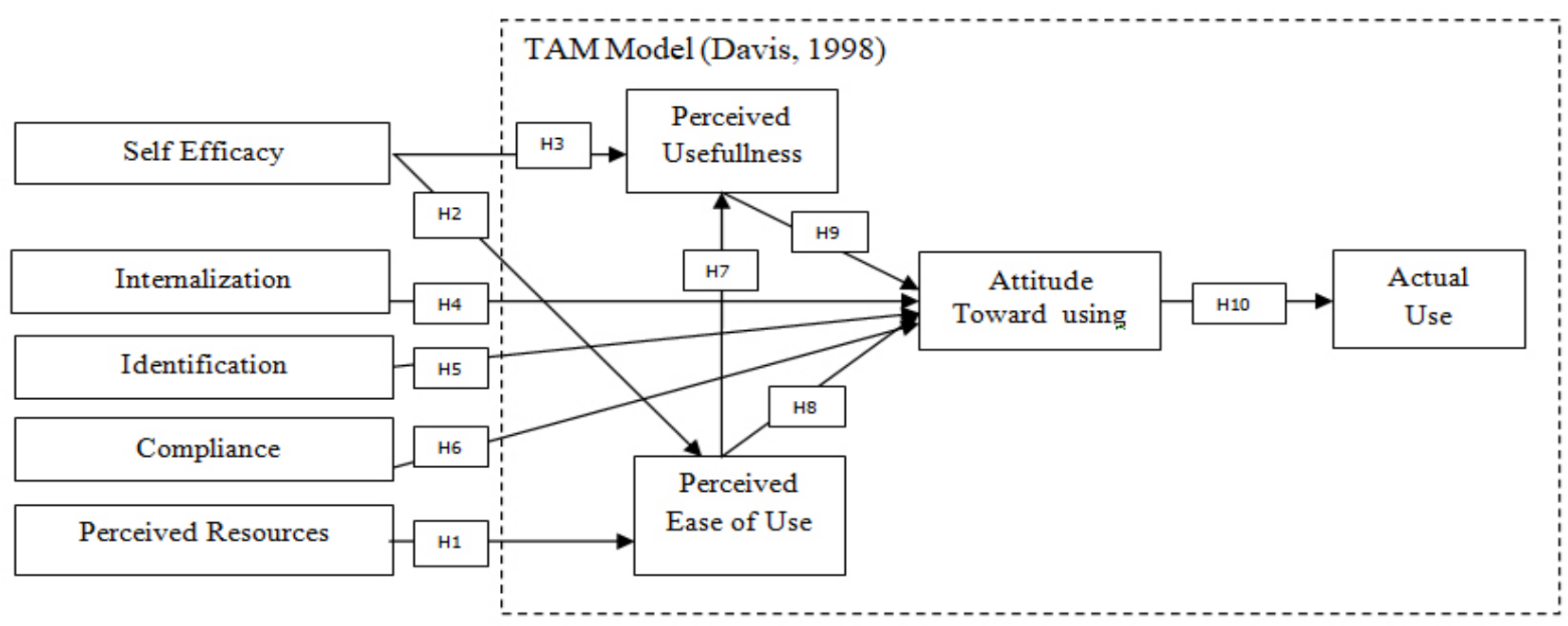

Gambar 2. Kerangka pemikiran penelitian 


\section{Attitude Toward Using}

Variabel attitude toward using terdiri dari lima indikator. Hasil dari data responden tersaji pada Tabel 3 diketahui lebih dari 90 persen responden mempersepsikan puas menggunakan BRISPOT, lebih lanjut hampir 5 persen responden tidak puas menggunakan BRISPOT. Responden yang mempersepsikan tidak puas menggunakan BRISPOT dalam bekerja adalah responden laki-laki dengan usia diatas 30 tahun dan sudah bekerja di BRI lebih dari 10 tahun.

\section{Actual Use}

Variabel actual use terdiri dari dua indikator (Tabel 4). Berdasarkan hasil perhitungan dari top two boxes diketahui bahwa lebih dari 80 persen menjadi pertimbangan respondenuntukmenggunakanBRISPOT dalam bekerja. Responden yang menggunakan BRISPOT untuk memprakarsai kredit lebih dari 4 kali dalam 1 minggu adalah 3 dari 4 responden berjenis kelamin laki-laki dengan rentang usia 26 s.d 35 tahun, memilik masa kerja di BRI lebih dari 10 tahun dan sudah menggunakan BRISPOT selama dua tahun.

\section{Perceived Resources}

Variabel perceived resources terdiri dari lima indikator (Tabel 5). Hasil dari data responden menunjukan lebih dari 90 persen responden mempersepsikan sumber daya yang digunakanuntuk BRISPOT sudah memadai. Hanya kurang dari dua persen responden yang menyatakan sumber daya yang digunakan untuk BRISPOT belum memadai. Responden yang mempersepsikan sumber daya BRISPOT belum memadai adalah perempuan dengan usia produktif diatas 30 tahun, sudah bekerja di BRI lebih dari 5 tahun dan pengalaman menggunakan BRISPOT selama satu tahun.

\section{Self Efficacy}

Variabel selfefficacy terdiri dari lima indikator. Hasil dari data responden tersaji pada Tabel 6 lebih dari 90 persen responden mempersepsikan memiliki kemampuan diri dalam menyelesaikan pekerjaan. Hanya kurang dari satu persen responden yang belum memiliki keyakinan akan kemampuan dirinya dalam menyelesaikan pekerjaan. Responden tersebut merupakan tenaga pemasar perempuan dengan usia kurang dari 30 tahun dan sudah bekerja di BRI selama 5 tahun.
Tabel 1. Sebaran responden berdasarkan indikator perceived ease of use

\begin{tabular}{lccc}
\hline Indikator & Tidak Setuju & Netral & Setuju \\
\hline PEOU1 & 2,42 & 3,23 & 94,35 \\
PEOU2 & 1,61 & 2,42 & 95,97 \\
PEOU3 & 1,61 & 6,45 & 91,94 \\
PEOU4 & 1,61 & 4,84 & 93,55 \\
PEOU5 & 2,42 & 3,23 & 94,35 \\
Rata-rata Persentase & 1,93 & 4,04 & 94,03 \\
\hline
\end{tabular}

Tabel 2. Sebaran responden berdasarkan indikator perceived usefulness

\begin{tabular}{lccc}
\hline Indikator & Tidak Setuju & Netral & Setuju \\
\hline PU1 & 1,61 & 4,03 & 94,35 \\
PU2 & 1,61 & 2,42 & 95,97 \\
PU3 & 1,61 & 5,65 & 92,74 \\
PU4 & 1,61 & 5,65 & 92,74 \\
PU5 & 2,42 & 12,90 & 84,68 \\
Rata-rata persentase & 1,77 & 6,13 & 92,10 \\
\hline
\end{tabular}

Tabel 3. Sebaran responden berdasarkan indikator attitude toward using

\begin{tabular}{lccc}
\hline Indikator & Tidak Setuju & Netral & Setuju \\
\hline ATU1 & 1,61 & 1,61 & 96,77 \\
ATU2 & 1,61 & 1,61 & 96,77 \\
ATU3 & 0,81 & 2,42 & 96,77 \\
ATU4 & 0,81 & 6,45 & 92,74 \\
ATU5 & 0,81 & 5,65 & 93,55 \\
Rata-rata Persentase & 1,13 & 3,54 & 95,32 \\
\hline
\end{tabular}

Tabel 4. Sebaran responden berdasarkan indikator actual use

\begin{tabular}{ccc}
\hline Simbol & Sering & Selalu \\
\hline AU1 & 10,48 & 89,52 \\
AU2 & 20,97 & 79,03 \\
Rata-rata persentase & 15,73 & 84,27 \\
\hline
\end{tabular}

Tabel 5. Sebaran responden berdasarkan indikator perceived resources

\begin{tabular}{lccc}
\hline Simbol & Tidak Setuju & Netral & Setuju \\
\hline PR1 & 0,00 & 4,03 & 95,97 \\
PR2 & 8,87 & 12,90 & 78,23 \\
PR3 & 0,00 & 5,65 & 94,35 \\
PR4 & 0,81 & 8,87 & 90,32 \\
PR5 & 0,00 & 5,65 & 94,35 \\
Rata-rata Persentase & 1,94 & 7,42 & 90,65 \\
\hline
\end{tabular}




\section{Internalization}

Variabel internalization terdiri dari tiga indikator. Hasil dari data responden tersaji pada Tabel 7 sebanyak 82,80 persen responden mempersepsikan bahwa menerima pengaruh atau perubahan tanpa paksaan dari orang lain atau lingkungan sekitar. Namun masih terdapat sembilan persen responden yang belum dapat menerima perubahan karena adanya paksaan dari orang lain tanpa kesadaran dari diri responden.

\section{Identification}

Variabel identification terdiri dari dua indikator. Hasil dari data responden tersaji pada Tabel 8 dimana hampir 90 persen responden mempersepsikan menerima perubahan untuk tetap mempertahankan hubungan dengan orang lain atau perusahaan. Hanya kurang dari tiga persen yang belum dapat menerima perubahan hanya untuk mempertahankan hubungannya dengan perusahaan.

\section{Compliance}

Variabel compliance terdiri dari empat indikator dimana sebagian besar responden 64 persen mempersepsikan menerima pengaruh atau perubahan untuk menghindari hukuman atau mendapatkan reward atas apa yang responden lakukan (Tabel 9). Namun ada 23 persen responden yang belum dapat menerima pengaruh dari orang lain karena takut menerima hukuman, responden yang mempersepsikan hal tersebut adalah 3 dari 4 responden berjenis kelamin laki-laki dengan usia diatas 30 tahun dan telah bekerja di BRI lebih dari lima tahun.

\section{Uji Kecocokan Model Pengukuran}

Validitas indikator dilihat dari nilai Loading Factor (LF), nilai $\mathrm{LF}$ indikator $\geq 0,5$ dikatakan valid (Marginigsih 2019). Dari hasil uji kecocokan model masih terdapat indikator yang memiliki factor loading $<0,50$ yaitu indikator INT3 $(0,47)$ dan CMP3 $(0,41)$ sehingga kedua indikator tersebut dikeluarkan dari diagram penelitian selanjutnya dan tidak dimasukan dalam perhitungan average variance extracted (AVE) dan composite reliability (CR).

\section{Evaluasi Reliabilitas Model}

Berdasarkan uji convergent validity nilai AVE seluruh peubah laten memiliki nilai $>0,5$. Dengan demikian, dapat dikatakan bahwa model memiliki validitas dengan indikator reflektif yang baik. Selain itu nilai composite reliability setiap peubah memiliki nilai $>0,7$ dengan demikian dapat diartikan bahwa konstruk laten memiliki konsistensi yang baik.

\section{Hasil Pengujian Hipotesis}

Pengujian hipotesis pada penelitian ini melalui pengujian koefisien jalur pada model persamaan structural dengan menggunakan software SmartPLS 3 (Gambar 3) nilai t-hitung >1.96 maka dapat dikatakan bahwa pengaruh variabel tersebut signifikan.

Tabel 7. Sebaran responden berdasarkan indikator internalization

\begin{tabular}{lccc}
\hline Simbol & Tidak Setuju & Netral & Setuju \\
\hline INT1 & 0,00 & 2,42 & 97,58 \\
INT2 & 5,65 & 3,23 & 91,13 \\
INT3 & 22,58 & 17,74 & 59,68 \\
Rata-rata persentase & 9,41 & 7,80 & 82,80 \\
\hline
\end{tabular}

Tabel 8. Sebaran responden berdasarkan indikator identification

\begin{tabular}{lccc}
\hline Simbol & Tidak Setuju & Netral & Setuju \\
\hline IDN1 & 3,23 & 8,06 & 88,71 \\
IDN2 & 2,42 & 8,06 & 89,52 \\
Rata-rata Persentase & 2,82 & 8,06 & 89,11 \\
\hline
\end{tabular}

Tabel 9. Sebaran responden berdasarka indikator compliance

\begin{tabular}{lccc}
\hline Simbol & Tidak Setuju & Netral & Setuju \\
\hline CMP1 & 23,39 & 12,10 & 64,52 \\
CMP2 & 17,74 & 14,52 & 67,74 \\
CMP3 & 33,06 & 4,03 & 62,90 \\
CMP4 & 18,55 & 20,16 & 61,29 \\
Rata-rata Persentase & 23,19 & 12,70 & 64,11 \\
\hline
\end{tabular}




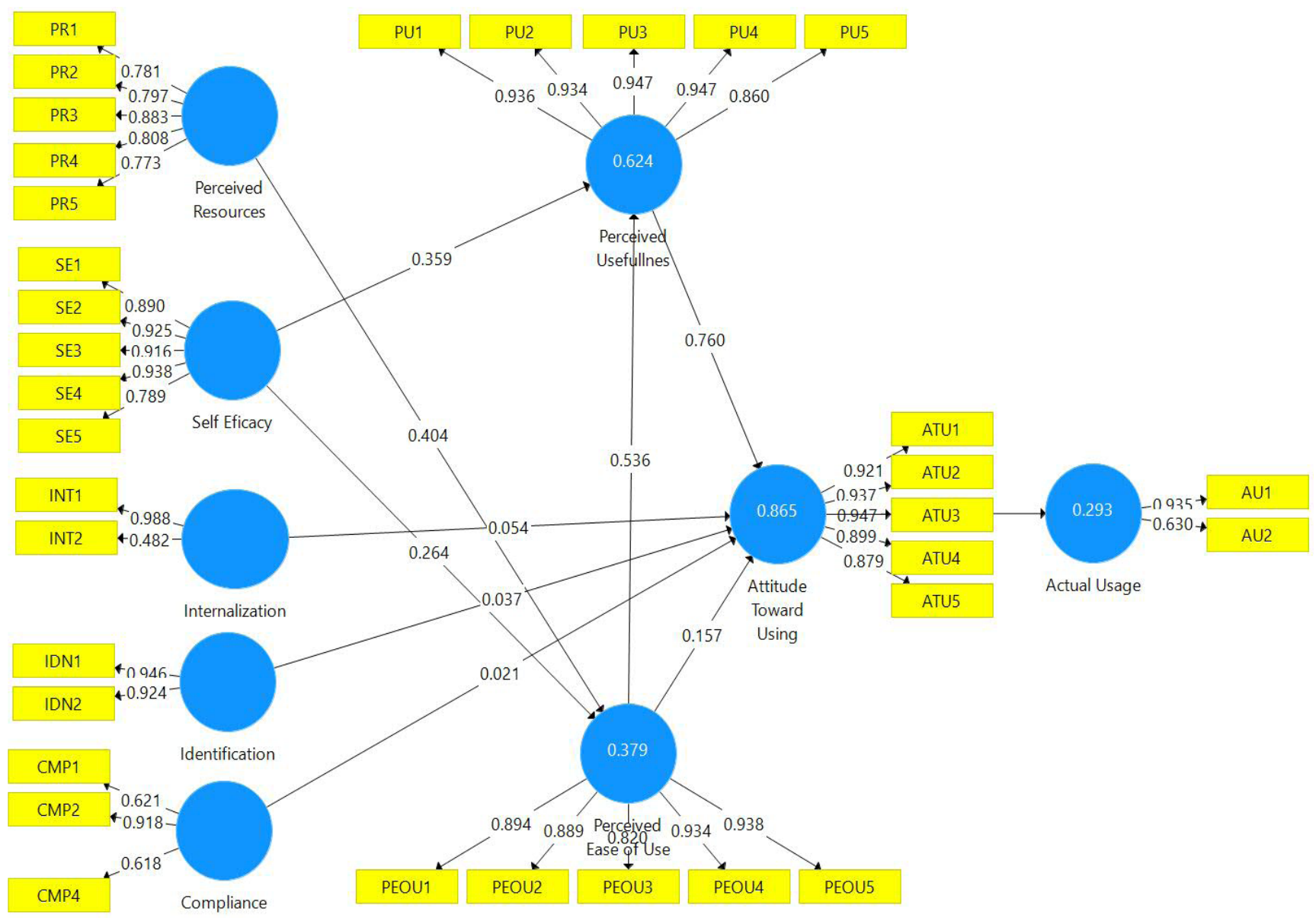

Gambar 3. Model SEM yang dihasilkan

H1: Pengaruh perceived resources terhadap perceived ease of use

Berdasarkan hasil penelitian didapatkan hasil bahwa perceived resources berpengaruh signifikan terhadap variabel perceived ease of use. Analisis tersebut sesuai dengan hasil penelitian yang telah dilakukan oleh Adhiputra (2015) yang menyatakan bahwa perceived resources berpengaruh signifikan terhadap perceived ease of use.

H2: Pengaruh self efficacy terhadap perceived ease of use.

Berdasarkan hasil penelitian didapatkan hasil bahwa Self efficacy berpengaruh signifikan terhadap variabel perceived ease of use. Analisis tersebut sesuai dengan hasil penelitian yang telah dilakukan oleh Lule et al. (2012) yang menyatakan bahwa self efficacy berpengaruh signifikan terhadap perceived ease of use.
H3: Pengaruh self efficacy terhadap perceived usefulness

Hasil penelitian didapatkan hasil bahwa self efficacy tidak berpengaruh signifikan terhadap variabel perceived usefulness. Analisis tersebut tidak sesuai dengan hasil penelitian yang telah dilakukan oleh Kartika (2009) yang menyatakan bahwa self efficacy berpengaruh signifikan terhadap perceived usefulness. Persepsi self efficacy tidak berpengaruh terhadap perceived usefulness karena kekurangyakinan pekerja bahwa walaupun aplikasi BRSIPOT bermanfaat dalam pekerjaan responden tetapi belum tentu dapat meningkatkan pencapaian target kerja.

H4: Pengaruh internalization terhadap attitude toward using

Hasil penelitian didapatkan hasil bahwa internalization tidak berpengaruh signifikan terhadap variabel attitude toward using. Analisis tersebut tidak sesuai dengan hasil penelitian yang telah dilakukan oleh Parreno et 
al. (2015) yang menyatakan bahwa internalization berpengaruh signifikan terhadap attitude toward using. Internalization tidak berpengaruh terhadap attitude toward using dikarenakan responden masih tidak nyaman bekerja dengan sistem yang berbeda dari yang dilakukan sehingga responden kurang senang dan kurang tertarik menggunakan BRISPOT dalam bekerja. Perasaan kurang senang dan kurang tertarik berdampak pada sikap responden terhadap penggunaan aplikasi BRISPOT.

H5: Pengaruh identification terhadap attitude toward using.

Berdasarkan hasil penelitian didapatkan hasil bahwa identification tidak berpengaruh siginifkan terhadap variabel attitude toward using. Analisis tersebut tidak sesuai dengan hasil penelitian yang telah dilakukan oleh Malhotra dan Galleta (2005) yang menyatakan bahwa identification berpengaruh signifikan terhadap attitude toward using. Identification tidak berpengaruh terhadap attitude toward using dikarenakan pengaruh dari atasan atau teman kantor belum berdampak terhadap sikap suka dan tidak suka responden menggunakan aplikasi BRISPOT.

H6: Pengaruh compliance terhadap attitude toward using.

Berdasarkan hasil penelitian didapatkan hasil bahwa compliance tidak berpengaruh signifikan terhadap variabel attitude toward using. Analisis tersebut sesuai dengan hasil penelitian yang telah dilakukan oleh Malhotra dan Galleta (2005) yang menyatakan bahwa compliance berpengaruh signifikan terhadap attitude toward using. Berdasarkan hasil penelitian ini menunjukan persepsi bahwa kesukarelaan responden untuk menggunakan sistem yang baru tidak berkaitan dengan suka atau tidak suka menggunakan BRISPOT.

H7: Pengaruh perceived ease of use terhadap perceived usefulness.

Berdasarkan hasil penelitian didapatkan hasil bahwa perceived ease of use berpengaruh signifikan terhadap variabel perceived usefulness. Analisis tersebut sesuai dengan hasil penelitian yang telah dilakukan oleh Khedmatgozar dan Shahnazi (2005) yang menyatakan bahwa perceived ease of use berpengaruh signifikan terhadap perceived usefulness. Berdasarkan hasil penelitian ini menunjukkan persepsi bahwa semakin mudah aplikasi BRISPOT digunakan maka akan semakin tinggi kemanfaatannya bagi responden.

H8: Pengaruh perceived ease of use terhadap attitude toward using

Berdasarkan hasil penelitian didapatkan hasil bahwa perceived ease of use tidak berpengaruh signifikan terhadap variabel attitude toward using. Analisis tersebut sesuai dengan hasil penelitian yang telah dilakukan oleh Kartika (2009) yang menyatakan bahwa perceived ease of use tidak berpengaruh signifikan terhadap attitude toward using.

H9: Pengaruh perceived usefulness terhadap attitude toward using.

Berdasarkan hasil penelitian didapatkan hasil bahwa perceived usefulness berpengaruh signifikan terhadap variabel attitude toward using. Analisis tersebut sesuai dengan hasil penelitian yang telah dilakukan oleh Sivo et al. (2016) yang menyatakan bahwa perceived usefulness berpengaruh signifikan terhadap attitude toward using. Berdasarkan hasil penelitian ini menunjukan persepsi bahwa semakin tinggi pemanfataan aplikasi BRISPOT, maka akan semakin positif sikap responden terhadap penggunaan aplikasi BRISPOT.

H10: Pengaruh attitude toward using terhadap actual use

Berdasarkan hasil penelitian didapatkan hasil bahwa attitude toward using berpengaruh signifikan terhadap variabel actual use. Analisis tersebut sesuai dengan hasil penelitian yang telah dilakukan oleh Murdiyanti (2016) yang menyatakan bahwa attitude toward using berpengaruh signifikan terhadap actual use. Berdasarkan hasil penelitian ini menunjukan persepsi bahwa semakin suka dan puas responden menggunakan BRISPOT, maka akan semakin positif perilaku responden dalam menggunakanya.

\section{Implikasi Manajerial}

Pada penelitian ini untuk merumuskan prioritas perusahaan dalam meningkatkan kinerja BRISPOT digunakan IPMA sebagai analisis tambahan dengan menghitung nilai rata-rata dari importance dan performance indikator dari variabel yang memengaruhi sistem BRISPOT yaitu perceived ease of use, perceived usefulness dan perceived resources. Menurut 
Ramayah et al. (2018) IPMA dapat digunakan untuk mengembangkan hasil dari Smart PLS atau menemukan saran pengembangan berdasarkan skor dari variabel laten. Hasil rataan importance dan performance dari masing-masing variabel dapat dilihat pada Gambar 4.

Menurut Latan dan Noonan (2017) secara umum Importance and Performance Matrix Analysis membangun peta dua dimensi yang didapatkan berdasarkan hasil survei kepuasan pelanggan dengan menggambarkan performance dalam garis horizontal dan menggunakan importance dalam garis vertikal. Pada Gambar 4 didapat nilai rata-rata seluruh indikator untuk importance sebesar 0,06 dan nilai rata-rata keseluruhan performance sebesar 82,80. Berdasarkan hasil pemetaan IPMA pada Gambar 4 terdapat satu indikator yang berada pada kuadran I yaitu PU5 (BRISPOT memiliki fitur-fitur yang berfungsi dengan baik) yang menjadi prioritas untuk dapat ditingkatkan.

Perbaikan pada PU5 (BRISPOT memiliki fitur-fitur yang berfungsi dengan baik) diterapkan dalam bentuk diferensiasi pada yaitu manajemen dapat memperbaiki fitur unggah foto usaha dan agunan karena permasalahan yang sering terjadi di lapangan adalah kendala mengunggah foto secara real time online pada saat kunjungan ke tempat debitur dan menambahkan fitur BRISPOT employee care pada aplikasi sehingga pekerja bisa langsung bertanya dan mendapatkan solusi atas permasalahan terhadap fitur yang mengalami gangguan, hal ini akan membantu proses kerja tenaga pemasar menjadi lebih cepat.

\section{KESIMPULAN DAN SARAN}

\section{Kesimpulan}

Perceived resources secara langsung berpengaruh signifikan terhadap perceived ease of use, sumber daya baik secara individu (kemampuan dan pengetahuan pekerja) dan hardware yang mendukung pada saat sistem baru diterapkan akan memberikan kemudahan bagi pekerja untuk mengoperasikannya. Self efficacy secara langsung berpengaruh signifikan terhadap perceived ease of use semakin tinggi persepsi responden mengenai potensi dirinya maka semakin tinggi persepsi bahwa apikasi BRISPOT mudah digunakan. Self efficacy tidak berpengaruh signifikan terhadap perceived usefulness karena kekurangyakinan responden bahwa walaupun aplikasi BRISPOT bermanfaat dalam pekerjaan belum tentu dapat meningkatkan pencapaian target kerja.

Internalization tidak berpengaruh signifikan terhadap attitude toward using dikarenakan responden masih tidak nyaman bekerja dengan sistem yang berbeda dari yang biasa dilakukan sehingga responden kurang senang dan kurang tertarik menggunakan BRISPOT dalam bekerja. Identification tidak berpengaruh signifikan terhadap attitude toward using dikarenakan pengaruh dari atasan atau teman kantor tidak berdampak terhadap sikap responden menggunakan aplikasi BRISPOT. Compliance tidak berpengaruh signifikan terhadap attitude toward using karena kesukarelaan responden untuk menggunakan sistem yang baru tidak berkaitan dengan suka atau tidak suka menggunakan BRISPOT.

Perceived ease of use berpengaruh signifikan terhadap variabel perceived usefulness. Semakin mudah aplikasi BRISPOT digunakan, maka akan semakin tinggi kemanfaatannya bagi responden. Perceived ease of use tidak berpengaruh signifikan terhadap attitude toward using karena mudah tidaknya aplikasi BRSIPOT digunakan tidak berkaitan dengan sikap suka dan tidak suka responden menggunakan BRISPOT. Perceived usefulness berpengaruh signifikan terhadap variabel attitude toward using semakin suka dan puas pekerja menggunakan BRISPOT, maka akan semakin positif perilaku responden dalam menggunakanya. Attitude toward using berpengaruh signifikan terhadap actual use BRISPOT. Semakin besar tingkat penerimaan suka dan rasa puas pekerja menggunakan BRISPOT maka frekuensi menggunakan BRISPOT menjadi lebih sering dalam memprakarsai kredit.

\section{Saran}

Untuk penelitian selanjutnya dengan tema yang sama, dapat dilakukan dengan menambahkan faktor-faktor yangmemengaruhikinerjapegawaidalammemprakarsai kredit menggunakan BRISPOT. Kemudian jika ingin memperdalam aspek self efficacy pekerja, penelitian berikutnya lebih difokuskan pada self efficacy pekerja yang baru diterima sebagai tenaga pemasar, sehingga perusahaan dapat menyiapkan SDM dan sistem yang mudah dan memberi manfaat dalam bekerja. Penelitian selanjutnya dapat mengkombinasikan model TAM dengan Theory of Planned Behavior (TPB) karena TPB menambahkan konsep persepsi pengendalian perilaku, yang berasal dari teori self efficacy. 


\section{DAFTAR PUSTAKA}

Adhiputra MW. 2015. Aplikasi technology acceptance model terhadap pengguna layanan internet banking. Jurnal Bisnis dan Komunikasi 2(1):5263.

Akturan U, Tezcan N. 2012. Mobile banking adoption of the youth market. Marketing Intelligence \& Planning 30(4):444-459.

Chrismastianto IAW. 2017. Analisis SWOT implementasi teknologi finansial terhadap kualitas layanan perbankan di Indonesia. Jurnal Ekonomi dan Bisnis 20(1):133-144.

Heryani IIP, Simanjuntak M, Maulana A. 2020. Perilaku penggunaan internet banking sebagai alat transaksi finansial: Behavioral usage of internet banking as financial transaction tool. Jurnal Aplikasi Bisnis Dan Manajemen (JABM) 6(1):86.

Indraswari GF. 2019. Analisis strategi digital bank BRI [tesis]. Yogyakarta: Universitas Gadjah Mada.

Kartika SE. 2009. Analisis proses penerimaan sistem informasi iCons dengan menggunakan technology acceptance model pada karyawan PT. Bank Negara Indonesia (Persero) Tbk di kota Semarang [tesis]. Semarang: Universita Diponegoro.

Khedmatgozar HR, Shahnazi A. 2018. The role of dimensions of perceived risk in adoption of corporate internet banking by customers in Iran. Electronic Commerce Research18(2):389-412.

Kustono AS. 2000. Faktor-faktor yang mempengaruhi tingkat penerimaan implementasi sistem informasi baru. Jurnal Riset Akuntansi Indonesia 14(3):11-13.

Liu Y, Li H. 2010. Mobile internet diffusion in China: An empirical study. Industrial Management And Data Systems 110(3):309-324.

Lule IO, Tonny K, Waema TM. 2012. Application of technology acceptance model (TAM) in $\mathrm{m}$-banking adoption in Kenya. International Journal of Computing and ICT Research 6(1):3143.

Marginingsih R. 2019. Analisis SWOT technology financial (FinTech) terhadap industri perbankan. Cakrawala 19(1):55-60.

Parreno JM, Blas SS, Mafe CR, Manzano JA. 2013. Key factors of teenagers mobile advertising acceptance. Industrial Management \& Data System 133(5):732-749.

Rachbini W, Fahruddin S, Marissa GH, Emi R. 2019. Analisis niat pembelian ulang e-commerce mobile dengan pendekatan technology acceptance model (TAM). Jurnal Aplikasi Bisnis dan Manejemen (JABM) 3(5):530-540.

Rahadi DR, Zainal. 2015. Analisis technology acceptance model pada industri perbankan. Jurnal Sistem Informasi 7(2):837-851.

Riquelme HE, Rios RE. 2010. The moderating effect of gender in the adoption of mobile banking. International Journal of Bank Marketing 28(5):328-341.

Simanjuntak E. 2019. Analisis kesiapan teknologi terhadap penerimaan teknologi untuk mengevaluasi BNI fleksi eForm [tesis]. Yogyakarta: Universitas Gadjah Mada.

Sivo SA, Ku CH, Acharya P. 2018. Understanding how university student perceptions of resources affect technology acceptance in online learning courses. Australasian Journal of Educational Technology 34(4):72-91.

Venkatesh V, Thong JY, Xu X. 2012. Consumer acceptance and use of information technology: extending the unified theory of acceptance and use of technology. MISQuartely 36(1):157-178.

Wibowo HY, Wijayanto H, Daryanto HK. 2018. Faktor yang mempengaruhi minat penggunaan perpustakaan digital. Jurnal Aplikasi Manajemen dan Bisnis 4(3):245-249. 